Key messages

- Epidemiological studies suggest that there is a weakly positive association between coronary heart disease and chronic infection with Helicobacter pylori

- A number of reports have also claimed that there are strong correlations between infection with $H$ pylori and an increase in vascular risk factors, such as plasma fibrinogen concentrations

- Meta-analysis of 18 studies that involved 10000 people found no strong correlations between $H$ pylori seropositivity and vascular risk factors; previous findings of the existence of such correlations in small studies were largely or wholly due to chance or to the preferential publication of positive results

between $H$ pylori seropositivity and these vascular risk factors are largely due to chance, or selective publication, or both. The clinical implication is that if there is any relation between chronic H pylor $i$ infection and coronary heart disease, ${ }^{1}$ then it is not likely to be dependent on the risk factors described here.

Colin Baigent and Rory Collins commented helpfully on this paper; Eric Brunner (Whitehall-2 study), Paul Moayyedi (Leeds angiographic study), Steffen J Rosenstock (Glostrup population study), and Mark Woodward (Glasgow MONICA-3 study) provided unpublished numerical details from their studies.

Contributors: JD initiated and performed the study, drafted the manuscript, and is guarantor for the study. RP helped interpret the data and draft the manuscript.

Funding: JD was supported by a Rhodes scholarship and a Frohlich award.

Conflict of interest: None.

1 Danesh J, Collins R, Peto R. Chronic infections and coronary heart disease: is there a link? Lancet 1997;350:430-6.

2 Karttunen T, Niemela S. Increased blood leukocytes in patients with Campylobacter pylori. Ann Int Med 1990;112:232.

3 Karttunen TJ, Niemela S, Kerola T. Blood leukocyte differential in Helicobacter pylori infection. Dig Dis Sci 1996;41:1332-6.

4 Barnes RJ, Uff JS, Dent JC, Gear MWL, Wilkinson SP. Long term follow up of patients with gastritis associated with Helicobacter pylori infection. BrJ Gen Pract 1991;41:286-8.

5 Patel P, Mendall MA, Carrington D, Strachan DP, Leatham E, Molineaux $\mathrm{N}$, et al. Association of Helicobacter pylori and Chlamydia pneumoniae infections with coronary heart disease and cardiovascular risk factors. BMJ 1995;311:711-4.
6 Rosenstock SJ, Andersen LP, Bonnevie O, Jorgensen T. Serum lipids, body-indices, age at menarche, and Helicobacter pylori infection in 1756 Danish women. Gut 1996;39(suppl 3):A62

Wald NJ, Law MR, Morris JK, Bagnall AM. Helicobacter pylori infection and mortality from ischaemic heart disease: negative result from a large, prospective study. BMJ 1997:315:1199-1201.

8 Rathbone BJ, Martin D, Stephens J, Thompson JR, Samani NJ Helicobacter pylori infection does not influence the risk of acute myocardial infarction. Heart 1996;76:308-11.

9 Scragg RKR, Fraser A, Metcalf PA. Helicobacter pylori seropositivity and cardiovascular risk factors in a multicultural workforce. J Epidemiol Community Health 1996;50:578-9.

10 Murray LJ, Bamford KB, O'Reilly DPJ, McCrum EE, Evans AE. Helicobacter pylori infection: relation with cardiovascular risk factors, ischaemic heart disease, and social class. Br Heart J 1995;74:497-501.

11 Niemela S, Karttunen T, Korhonen T, Laara E, Karttunen R, Ikaheimo M, et al. Could Helicobacter pylori infection increase the risk of coronary heart disease by modifying serum lipid concentrations? Heart 1996;75:573-5.

12 Whincup PH, Mendall MA, Perry IJ, Strachan DP, Walker M. Prospective relations between Helicobacter pylori infection, coronary heart disease, and stroke in middle-aged men. Heart 1996;75:568-72.

13 Lip GH, Wise R, Beevers G. Association of Helicobacter pylori with coronary heart disease. $B M J$ 1996;312:250-1.

14 Brunner E, Mendall M, Marmot M. Past or present Helicobacter pylori infection and fibrinogen-a possible link between social class and coronary risk? J Epidemiol Community Health 1995;49:545.

15 McDonagh TA, Woodward M, Morrison C, McMurray J, Tunstall-Pedoe $\mathrm{H}$, Lowe GDO, et al. Lack of independent association of $\mathrm{H}$ pylori and coronary heart disease. Eur Heart J 1997;18:1257-60.

16 Ossei-Gerning N, Moayyedi P, Smith S, Braunholtz D, Wilson JI, Axon ATR, et al. Helicobacter pylori infection is related to atheroma in patients undergoing coronary angiography. Cardiovasc Res 1997;35:120-4.

17 Patel P, Carrington D, Strachan DP, Leatham E, Goggin P, Northfield TC et al. Fibrinogen: a link between chronic infection and coronary heart disease. Lancet 1994;343:1634-5.

18 Carter AN, Moayyedi P, Catto A, Heppell RM, Axon TR, Grant PJ. The influence of Helicobacter pylori status on circulating levels of the coagulation factors fibrinogen, von Willebrand factor, factor VII, and factor VIII. Helicobacter 1996;1:65-9.

19 Parente F, Maconi G, Imbesi V, Sangaletti O, Poggio M, Rossi E, et al. Helicobacter pylori infection and coagulation in healthy people. $B M J$ 1997;314:1318-9.

20 Mendall MA, Goggin PM, Molineaux N, Levy J, Toosy T, Strachan D, et al. Relation of Helicobacter pylori infection and coronary heart disease. $\mathrm{Br}$ Heart J 1994;71:437-9.

21 Martin de Argila C, Boixeda D, Canton N, Mir N, Gisbert JP, de Rafael L, et al. Leukocyte differential count and Helicobacter pylori infection. Gut 1997;41(suppl 3):A173.

22 Mendall MA, Patel P, Ballam L, Strachan D, Northfield TC. C reactive protein and its relation to cardiovascular risk factors: a population based cross sectional study. BMJ 1996;312:1061-5.

23 Lip GYH, Wise R, Beevers G. Association of Helicobacter pylori infection with coronary heart disease. BMJ 1996;312:250-1.

24 Brenner H, Rothenbacher D, Bode G, Adler G. Relation of smoking and alcohol and coffee consumption to active Helicobacter pylori infection: cross sectional study. BMJ 1997;315:1489-92.

(Accepted 22 December 1997)

\title{
Growth hormone as a risk for premature mortality in healthy subjects: data from the Paris prospective study
}

Patrick Maison, Beverley Balkau, Dominique Simon, Philippe Chanson, Gabriel Rosselin, Eveline Eschwège

Institut National de la Santé et de la Recherche Médicale Unité 21, Faculté de Médecine Paris Sud, Villejuif, France Patrick Maison, epidemiologist Beverley Balkau research director, Dominique Simon endocrinologist Eveline Eschwège, unit director

continued over

BMJ 1998;316:1132-3
The influence of growth hormone on mortality in adults is well known in conditions such as growth hormone deficiency and acromegaly. ${ }^{12}$ In both diseases the excess mortality is principally from cardiovascular disorders, but the occurrence of malignant disorders has also been reported in acromegaly. ${ }^{2}$ To our knowledge the long term effect of physiological growth hormone on mortality in healthy adults has not been reported.

\section{Subjects, methods and results}

We studied 864 policemen aged 48 to 52 years who did not have cardiovascular disease, diabetes, or glucose intolerance and who had complete data in the Paris prospective study. ${ }^{3}$ They were examined between 1967 and 1973 then followed for mortality until January 1989. The body mass index (weight $(\mathrm{kg}) /\left(\right.$ height $\left.(\mathrm{m})^{2}\right)$ ), ratio of iliac to thigh circumference (a marker of central fat distribution), heart rate, and both diastolic and systolic blood pressures were measured and smoking habits determined. Blood samples were taken at fasting to measure cholesterol and triglyceride concentrations and mean corpuscular volume, and both at fasting and 2 hours after a $75 \mathrm{~g}$ oral glucose tolerance test for concentrations of non-esterified fatty acids, glucose, insulin, and growth hormone with a technique described previously. 
Hazard ratios (95\% confidence intervals) in Paris prospective study cohort (864 men, 48-52 years, 18 year follow up) of factors predictive of death from all causes, from cardiovascular disorders and from malignant disorders from a multivariate Cox model analysis. Variables are presented in order of entry into model using a forward method after adjustment for age

\begin{tabular}{|c|c|c|}
\hline Factors in order of entry into model & Hazard ratios & $P$ value \\
\hline \multicolumn{3}{|l|}{ All causes } \\
\hline Systolic blood pressure $(\mathrm{mm} \mathrm{Hg})$ & $1.02(1.01$ to 1.02$)$ & $<0.0001$ \\
\hline Smoking (cigarettes/day) & $1.04(1.03$ to 1.06$)$ & $<0.0001$ \\
\hline Fasting fatty acids $(\mathrm{mg} / \mathrm{l})^{*}$ & 2.45 (1.61 to 3.72$)$ & $<0.0001$ \\
\hline 2 hour growth hormone $(\mu \mathrm{g} / \mathrm{l}) \ddagger$ & 2.54 (1.51 to 4.27$)$ & 0.002 \\
\hline \multicolumn{3}{|l|}{ Mean corpuscular volume (fl)†: } \\
\hline Mean $v$ mean+SD & $1.21(0.97$ to 1.51$)$ & 0.07 \\
\hline Mean $v$ mean-SD & $0.95(0.76$ to 1.18$)$ & \\
\hline Fasting growth hormone $(\mu \mathrm{g} / \mathrm{l}) \ddagger$ & 1.50 (1.12 to 2.02$)$ & 0.009 \\
\hline \multicolumn{3}{|l|}{ Cardiovascular disorders } \\
\hline Diastolic blood pressure $(\mathrm{mm} \mathrm{Hg})$ & $1.04(1.02$ to 1.05$)$ & $<0.0001$ \\
\hline Mean corpuscular volume (fl) & $1.06(1.01$ to 1.12$)$ & 0.02 \\
\hline Fasting growth hormone $(\mu \mathrm{g} / \mathrm{l}) \ddagger$ & $1.79(1.00$ to 3.18$)$ & 0.05 \\
\hline Smoking (cigarettes/day) & $1.03(1.00$ to 1.06$)$ & 0.06 \\
\hline \multicolumn{3}{|l|}{ Malignant disorders } \\
\hline Smoking (cigarettes/day) & 1.06 (1.04 to 1.08$)$ & $<0.0001$ \\
\hline Fasting fatty acids $(\mathrm{mg} / \mathrm{l})^{*}$ & $2.88(1.49$ to 5.57$)$ & 0.002 \\
\hline Mean corpuscular volume (fl) & $1.06(1.01$ to 1.10$)$ & 0.01 \\
\hline 2 hour growth hormone $(\mu \mathrm{g} / \mathrm{l}) \ddagger$ & 2.59 (1.17 to 5.73$)$ & 0.04 \\
\hline
\end{tabular}

$P$ values and hazard ratios are adjusted for variables already in the model. ${ }^{*} \log _{10}$ transformed.

$\dagger$ Non-linear relation (quadratic), hazard ratio, and $\mathrm{P}$ value were calculated for mean $(98.7 \mathrm{fl}) v$ mean+SD $(98.7+5.7=104.4 \mathrm{fl})$ and for mean $v$ mean-SD $(93.0 \mathrm{fl})$ $\ddagger$ Above $v$ below the median at 0 hour $(0.5 \mu \mathrm{g} / \mathrm{l})$ and the 95th centile at 2 hours $(1.1 \mu \mathrm{g} / \mathrm{l})$.

We excluded from this analysis the three men for whom acromegaly was likely, using the criteria of fasting growth hormone concentration $>10 \mu \mathrm{g} / \mathrm{l}$ and 2 hour growth hormone concentration $>5 \mu \mathrm{g} / \mathrm{l}$.

We studied deaths from all causes, from cardiovascular disorders, and from cancer. During the 18 years of follow up, 171 men died (64 deaths were due to malignant disorders, 49 to cardiovascular diseases).

Kaplan-Meier survival curves were estimated according to four classes of growth hormone (the limits corresponding to the limit of detection, the median, and the 95th centile) and compared by the Mantel-Cox test. The survival curves showed a significant difference for growth hormone concentration at 2 hours $(\mathrm{P}=0.03)$ and $\mathrm{a}$ trend at fasting $(\mathrm{P}=0.11)$, with a higher mortality above ( $v$ below) the median of $0.5 \mu \mathrm{g} / \mathrm{l}$ at fasting $(\mathrm{P}=0.02)$ and a higher mortality above ( $v$ below) the 95 th centile of $1.1 \mu \mathrm{g} / 1$ at 2 hours $(\mathrm{P}=0.004)$. Growth hormone concentrations were therefore analysed in two classes, chosen after this exploratory data analysis.

Cox proportional hazards models were used to estimate hazard ratios for risk factors for death, after adjustment for age. Variables significant in univariate models were entered into stepwise multivariate analyses. The table shows the hazards ratios of factors that predict death from all causes, from cardiovascular disorders, and from malignant disorders.

\section{Comment}

The original finding of this 18 year prospective study is the independent predictive power of higher concentrations of fasting and 2 hour growth hormone for mortality.
We used an old fashioned technique to measure growth hormone concentration, which was the reference at that time. ${ }^{4}$ A lack of assay precision would, however, have increased the variation of growth hormone within individuals, and the association between growth hormone concentration and mortality should be reduced and underestimated, not enhanced.

We could have excluded the 25 men (3\%) who had a 2 hour growth hormone concentration $>2 \mu \mathrm{g} / \mathrm{l}$, another level accepted for the diagnosis of acromegaly; the trend remained unchanged for fasting growth hormone concentration when they were excluded.

Four other independent risk factors were associated with early mortality, in agreement with a previous analysis of the complete cohort. ${ }^{3}$ For death from cardiovascular causes, fasting growth hormone-along with the two classic risk factors (arterial blood pressure and cigarette smoking)-seemed to be a risk factor. Indeed, a direct and causal relation between growth hormone and cardiovascular growth and function has previously been suggested. ${ }^{25}$ We found a significant relation for 2 hour growth hormone concentrations with death from cancer. Growth hormone is also known to play a role in cancer. ${ }^{2}$

Since growth hormone treatment is being extended, these disturbing results merit an exploration in other studies of healthy populations.

This study was presented at the 10th international congress of endocrinology, San Francisco, California, on 13 June 1996 (oral session OR37-1).

Contributors: PM initiated the research, participated in the analysis and interpretation of the data and in the discussion and writing of the paper, and is guarantor for the paper. BB participated in the project initiation, analysis of the data, protocol design, and writing of the paper. DS participated in the interpretation and discussion of the results as well as in the writing of the paper. PC participated in the discussion and interpretation of the results. GR participated in the data collection and biochemical measures. EE participated in the coordination, data collection, and the writing of the paper.

Funding: Institut National de la Santé et de la Recherche Médicale.

Conflict of interest: None.

1 Rosen T, Bengtsson BA. Premature mortality due to cardiovascular disease in hypopituitarism. Lancet 1990;336:285-8.

2 Bengtsson B, Eden S, Ernest I, Oden A, Sjogren B. Epidemiology and long term survival in acromegaly. Acta Med Scand 1988;223:327-35.

3 Balkau B, Eschwège E, Papoz L, Richard JL, Claude JR, Warnet JM, et al Risk factors for early death in non-insulin dependent diabetes and men with known glucose tolerance status. BMJ 1993;307:295-9.

4 Rosselin G, Assan R, Yalow RS, Berson SA. Separation of antibody bound and unbound peptide hormone labelled with iodine 131 by talcum powder and precipitated silica. Nature 1966;212:355-7.

5 Sacca L, Cittadini A, Fazio S. Growth hormone and the heart. Endocr Rer 1994;15:555-73.

(Accepted 16 December 1997)

\section{Endpiece}

A problem often confronting editors

He draweth out the thread of his verbosity finer than the staple of his argument.

Shakespeare, Love's Labours Lost, V.i
Service

d'Endocrinologie,

Hôpital de Bicêtre,

Le Kremlin-Bicêtre,

France

Philippe Chanson,

endocrinologist

Institut National de la Santé et de la

Recherche Médicale Unité 55, Hôpital

St Antoine, Paris

Gabriel Rosselin, unit director

Correspondence to: Dr P Maison,

INSERM U21,

Faculté de

Médecine Paris Sud,

16 avenue Paul

Vaillant Couturier,

94807 Villejuif

Cedex, France

maison@vjf.inserm.fr 